\title{
Environmental management of shrimp farms in Asia to promote healthy shrimp and reduce negative impacts
}

\author{
Claude E. Boyd* \\ Department of Fisheries and Allied Aquacultures, Auburn University, Alabama 36849 USA
}

\begin{abstract}
Shrimp production in Asia ranges from extensive culture of Penaeus monodon to superintensive culture of Litopenaeus vannamei. Farms often are small but there also are large farms, a few of which produce more shrimp than some shrimp producing countries in the Western Hemisphere. Production technology varies from primitive techniques to the most modern methods. There is a trend towards greater biosecurity by using disease-free broodstock, disinfection of source water and reduction in water exchange. Mechanical aeration allows for great increases in production, but most aerators used in Asia are low in efficiency compared to aerators used in the United States. Aerators cause much erosion in earthen ponds. Lined ponds allow for greater aeration and two to three times more shrimp production per hectare than in unlined ponds. Aeration requirements should be based on feed conversion efficiency, feed BOD, target DO concentration and aerator efficiency. Energy use in aeration is a major expense, often amounting to US\$0.40 or more per kilogram shrimp. Aerator efficiency could be improved through changes in aerator design. Moreover, a reduction in daytime aerator use when water usually contains plenty of dissolved oxygen could reduce electricity costs. At some farms, organic sediment is removed from lined ponds during the production cycle to lessen oxygen demand and increase the proportion of dissolved oxygen added by aerators available to shrimp. Biological oxidation of ammonia nitrogen in lined ponds causes total alkalinity concentration to decline and lime applications should be made at frequent intervals in proportion to feed input. The usual amount of lime needed is about 0.3 to $0.5 \mathrm{~kg} \mathrm{CaCO}_{3}$ equivalent per kilogram feed. There is no evidence that water quality in ponds can be improved through additions of zeolite, coagulants, microbial products (sometimes called probiotics) and other amendments. There is increasing attention on implementation of better management practices to lessen negative environmental impacts of shrimp farming and comply with eco-label certification programs.
\end{abstract}

$\overline{\text { *Corresponding author. E-mail address: boydce1@auburn.edu }}$ 


\section{Introduction}

Shrimp farmers in Asia rely upon a variety of production strategies. The major species traditionally was the black tiger prawn, $P$. monodon but several countries, particularly Thailand, Indonesia and China are currently producing large quantities of Pacific white shrimp, L. vannamei. Culture techniques range from semi-intensive with production of only a few hundred kilograms per hectare, to super-intensive with production of more than $10,000 \mathrm{~kg}^{\cdot h^{-1}}$. Biosecurity measures are frequently installed to lower disease risk and more attention is given to reducing the potential for water pollution and other negative environmental impacts.

The purpose of this report is to discuss how shrimp ponds are managed in Asia and to present suggestions for improvements that could enhance culture conditions and lessen negative environmental impacts. The discussion will focus on intensive and semi-intensive shrimp farming because little management is applied in extensive shrimp culture.

\section{The Culture Animals}

There is much debate about the wisdom of introducing non-native species, but L. vannamei has already been widely introduced in Asia. A lower crude protein concentration and less fish meal can be used in feed for L. vannamei than in feed for $P$. monodon (Fegan 2002a). Moreover, it is apparently easier to obtain disease-free broodstock of $L$. vannamei than P. monodon (Fegan 2002b). The introduction of $L$. vannamei has allowed farmers to realize greater survival, higher yields and lower production costs than are possible with P. monodon (Fegan 2007). Of course, the large production of L. vannamei in Asia has been a factor in the declining price of shrimp and escapes of $L$. vannamei from farms may eventually have negative impacts on native shrimp populations.

Widespread problems with viral diseases have caused farmers to seek specificpathogen-free postlarvae for stocking in ponds. Such postlarvae usually are acquired from hatcheries using disease-free broodstock and PCR tests often are used to confirm that postlarvae are free of specific pathogens.

\section{Pond Preparation}

Ponds are drained completely for harvest and there are several steps to prepare ponds to receive postlarvae for the next cycle (Suresh et al. 2006).Aerators generate currents that erode pond bottoms and the suspended particles settle in areas of the pond 
where water currents are weaker. Most farmers remove this sediment from pond bottoms between crops and almost all farmers allow pond bottoms to dry. It also is common practice to apply 500 to $2,000 \mathrm{~kg}^{\cdot \mathrm{ha}^{-1}}$ of liming material over bottoms of empty ponds. Tilling is sometimes done to enhance dry-out, but this practice favors erosion by aerators during the next production cycle. The best procedure would be to compact bottoms of ponds following tilling but this is seldom done.

Free viral particles apparently do not survive for more than a few days in water, so they can be eliminated by holding water for a few days before stocking postlarvae. However, various species of small shrimp, planktonic microcrustaceans and other aquatic animals can be vectors of viral disease. They survive longer than free viral particles and can serve as sources of viral diseases to infect newly-stocked, disease-free postlarvae.

Shrimp farmers often apply treatments to remove or kill disease vectors. Several methods are used to include liming, filtration, chlorination and dichlorvos treatment. Source water may be treated in reservoirs before adding it to ponds or water in ponds may be treated before stocking shrimp.

Fine mesh filters are necessary for removing microcrustaceans from water. Large volumes of water are needed to fill and maintain water levels in shrimp ponds. Filters for removing small crustaceans from water quickly become clogged and the fabric often rips. Filtration is usually not practical or effective for treating source water at large shrimp farms.

Liming is done with burnt lime (calcium oxide) or hydrated lime (calcium hydroxide). When added to a reservoir or pond at a rate of 1,500 to $2,000 \mathrm{~kg}^{-1} \mathrm{ha}^{-1}(0.15$ to $0.2 \mathrm{~kg}^{-3}$ ), lime can increase $\mathrm{pH}$ above 10 and kill aquatic organisms that are vectors of shrimp disease (Boyd and Tucker 1998). Lime is not highly soluble in water and is difficult to apply uniformly. It is virtually impossible to achieve a high $\mathrm{pH}$ throughout the water volume following lime treatment. Thus, liming is not highly effective in eliminating vectors of viral diseases.

Chlorination with calcium hypochlorite, commonly called high-test hypochlorite (HTH) can be effective in killing vectors of shrimp diseases (Baticados and Pitogo 1990). Chlorine residuals resulting from HTH application quickly are degraded to non-toxic form by sunlight and postlarvae can be safely stocked within 1 week following treatment. However, chlorine residuals also are rendered non-toxic by reaction with organic matter and other reduced substances in water and their toxicity declines with increasing $\mathrm{pH}$ (White, 1992). Source water for shrimp ponds usually has a 
$\mathrm{pH}$ around 8 and contains several milligrams per liter of dissolved and particulate organic matter. The effective treatment rate for $\mathrm{HTH}$ is normally 20.0 to $30.0 \mathrm{mg}^{\cdot} \mathrm{L}^{-1}$ (Potts and Boyd 1998; Boyd and Massaut 1999). HTH is expensive and most producers cannot afford to apply it at such a high concentration. Unfortunately, the effectiveness of treatment with lower concentrations is highly variable.

Dichlorvos, dimethyl 2,2-dichlorovinyl phosphate, often abbreviated as DDVP, is an organophosphate pesticide highly toxic to shrimp, zooplankton and other aquatic organisms (Johnson and Finley 1980). It has a short residual life in water and does not accumulate in shrimp. For example, data collected on one shrimp farm showed the following residues at different times after treatment with $3.0 \mathrm{mg}^{-1}$ of DDVP: $6 \mathrm{hr}$, $0.28 \mu \mathrm{g}^{\cdot} \mathrm{L}^{-1} ; 24 \mathrm{hr}, 0.21 \mu \mathrm{g}^{\cdot} \mathrm{L}^{-1} ; 2$ days, $0.1 \mu \mathrm{g}^{\cdot} \mathrm{L}^{-1} ; 3$ days, $0.05 \mu \mathrm{g}^{\cdot} \mathrm{L}^{-1} ; 4$ days, $0.03 \mu \mathrm{g}^{\cdot} \mathrm{L}^{-}$ ${ }^{1}$; 5 days, $0.01 \mu \mathrm{g}^{-1}$; 6 and 7 days, not detectable. Moreover, DDVP residue was not detected in shrimp tissue when shrimp were harvested 4 months later. Treatment of source water with DDVP at 2 to $3 \mathrm{mg} \cdot \mathrm{L}^{-1}$ active ingredient is an effective and economical technique for killing vectors of shrimp disease.

Dichlorvos must be handled carefully to avoid spills and possible toxicity to aquatic animals in the vicinity of farms. It also is toxic to humans and workers should wear protective gear to avoid breathing vapors or making direct skin contact with this compound. Nevertheless, it is no more environmentally hazardous or dangerous to workers than HTH. Even lime can be hazardous to workers because of its caustic properties. The main issue with DDVP is that environmentalists and the public tend to have a negative perception of most pesticides. This is unfortunate in the case of DDVP because treatment with this compound is probably the most reliable and safest way to destroy vectors of shrimp diseases in farm water supplies.

\section{Fate of Feeds in Ponds}

Natural productivity will not support over a few hundred $\mathrm{kg}^{\cdot h \mathrm{ha}^{-1}}$ shrimp (Boyd and Tucker 1998). Feed can be applied to increase shrimp production, but dissolved oxygen from natural sources usually will not support more than $1,000 \mathrm{~kg}^{\cdot \mathrm{ha}^{-1}}$ of shrimp. Feeding is a common practice for increasing shrimp production.

The fate of feed applied to aquaculture systems is illustrated in Fig. 1. Shrimp nibble feed pellets, and pellets disintegrate before they are completely ingested. In some cases, nearly half the organic carbon in feed pellets is not ingested (Ruttanagosrigit 1997); however, shrimp usually consume 85 to $90 \%$ of their feed. Shrimp feeds are of high quality, and up to 80 to $90 \%$ of dry matter that is eaten is absorbed across the intestine. The remainder is expelled as feces. Organic carbon 
absorbed across the intestine of shrimp is either oxidized in respiration or converted to biomass. Nitrogen not incorporated into shrimp biomass is excreted into the water as ammonia. Organic carbon and nitrogen in biomass are either catabolized and excreted as carbon dioxide and ammonia, or removed from the culture system at harvest. Uneaten feed and feces are decomposed by bacteria with organic carbon oxidized to carbon dioxide, and organic nitrogen mineralized to ammonia.

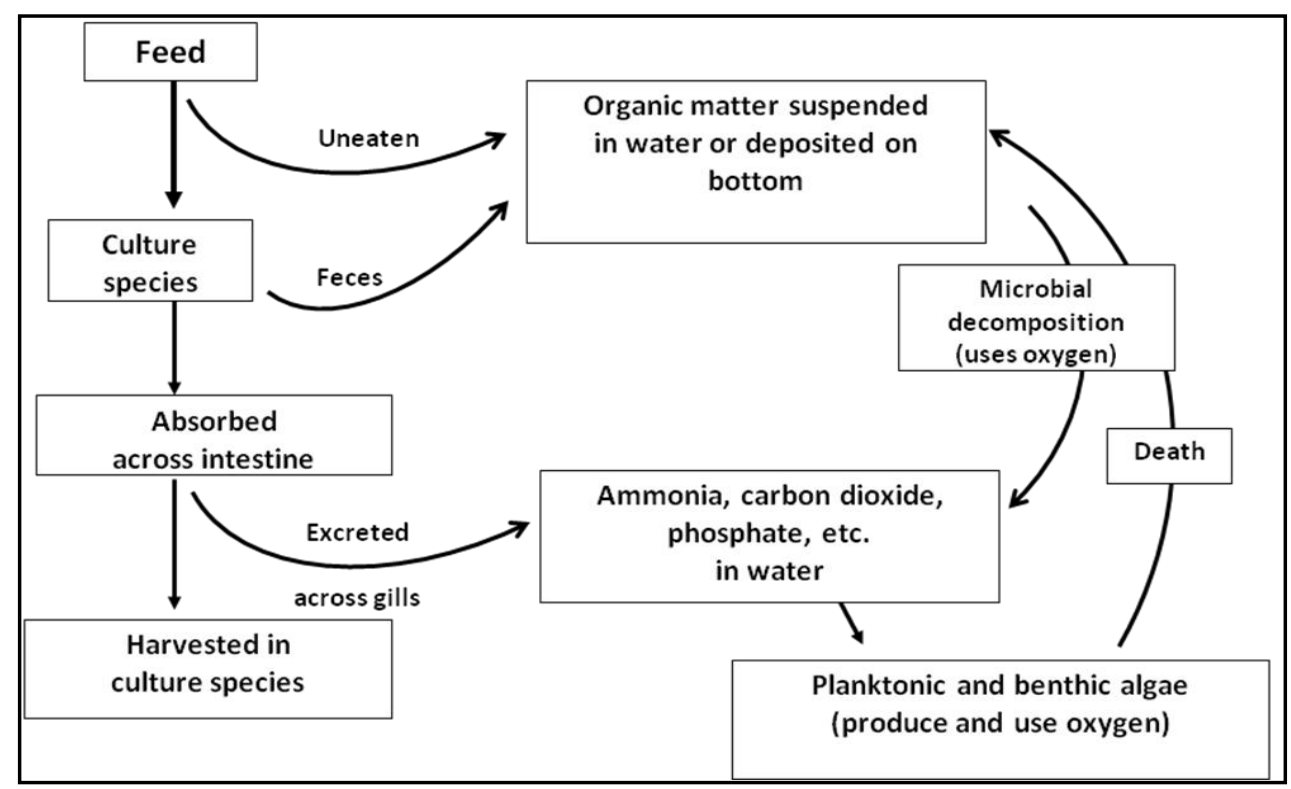

Fig. 1. Fate of feeds in aquaculture ponds.

In summary, some of the organic carbon and nitrogen added to shrimp ponds in feed becomes biomass and is harvested. The rest of it is oxidized to carbon dioxide, or mineralized to ammonia by shrimp and bacteria. The majority of uneaten feed and feces will be oxidized and mineralized, and nitrifying bacteria in pond water will oxidize ammonia to nitrate.

Phosphorus also enters pond water as a waste from feed. Thus, feeding increases the availability of carbon dioxide, ammonia, nitrate and phosphate, resulting in greater phytoplankton productivity. Accumulation of organic carbon in biomass, detritus, and sediment in un-aerated ponds is irrefutable evidence that more oxygen is produced in photosynthesis than used by respiration of the biota in the short term. Nevertheless, much of the oxygen produced by phytoplankton is used in their respiration or in respiration of heterotrophic microorganisms that degrade dead phytoplankton. Aeration usually must be applied in ponds with feeding rates over 30 $\mathrm{kg}^{\cdot} \mathrm{ha}^{-1}$ per day (Boyd and Tucker 1998). 


\section{BOD of Feed}

The BOD of feed can be defined as the amount of oxygen required to oxidize organic carbon and nitrogen applied to ponds in feed but not recovered in shrimp at harvest. Organic carbon oxidation has the same stoichiometry regardless of whether it is done by bacteria or by shrimp:

$$
\text { Organic } \mathrm{C}+\mathrm{O}_{2} \rightarrow \mathrm{CO}_{2}
$$

Oxidation of 12 units of organic carbon requires 32 units oxygen $-2.67 \mathrm{~kg}$ $\mathrm{O}_{2} \mathrm{~kg}^{-1}$ organic $\mathrm{C}$. The summary equation for oxidation of ammonia nitrogen by nitrifying bacteria is:

$$
\mathrm{NH}_{4}^{+}+2 \mathrm{O}_{2} \rightarrow \mathrm{NO}_{3}^{-}+2 \mathrm{H}^{+}+\mathrm{H}_{2} \mathrm{O}
$$

Oxidation of 14 units of ammonia nitrogen requires 64 units of molecular oxygen $-4.57 \mathrm{~kg} \mathrm{O}_{2} \mathrm{~kg}^{-1}$ ammonia $\mathrm{N}$.

Feed for L. vannamei usually contains about $45 \%$ organic carbon and $5.6 \%$ nitrogen. A feed conversion ratio (FCR) of 1.8 often is achieved and live, harvestablesized L. vannamei contain about $11 \%$ carbon and $2.86 \%$ nitrogen (Boyd and TeichertCoddington, 1995). One kilogram of feed contains $0.45 \mathrm{~kg}$ organic carbon and $0.056 \mathrm{~kg}$ organic nitrogen. It produces $0.556 \mathrm{~kg}$ live shrimp containing $0.061 \mathrm{~kg}$ organic carbon and $0.016 \mathrm{~kg}$ organic nitrogen. Thus, $0.389 \mathrm{~kg}$ organic carbon and $0.04 \mathrm{~kg}$ ammonia nitrogen must be oxidized for each kilogram of feed applied. Oxidation of organic carbon will require $1.039 \mathrm{~kg} \mathrm{O}{ }^{\circ} \mathrm{kg}^{-1}$ feed and oxidation of ammonia will require an additional $0.183 \mathrm{~kg} \mathrm{O}_{2} \mathrm{~kg}^{-1}$ feed - the BOD of the feed in this example is $1.22 \mathrm{~kg} \mathrm{O}_{2} \mathrm{~kg}^{-}$ 1 feed.

Calculations for the BOD of feed can be arranged into an equation (Boyd, 2009) as follows:

$$
\mathrm{BOD}_{\mathrm{f}}=\left[\mathrm{C}_{\mathrm{f}}-\left(\mathrm{FCE} \times \mathrm{C}_{\mathrm{s}}\right)\right] 2.67+\left[\mathrm{N}_{\mathrm{f}}-\left(\mathrm{FCE} \times \mathrm{N}_{\mathrm{s}}\right)\right] 4.57
$$

where $\mathrm{BOD}_{\mathrm{f}}=$ feed BOD $\left(\mathrm{kg} \mathrm{O}_{2} \mathrm{~kg}^{-1}\right.$ feed $) ; \mathrm{C}_{\mathrm{f}}, \mathrm{N}_{\mathrm{f}}, \mathrm{C}_{\mathrm{s}}, \mathrm{N}_{\mathrm{s}}=$ decimal fractions, $\% / 100$, of carbon and nitrogen in feed and shrimp, respectively; FCE = feed conversion efficiency. The FCE is the inverse of the feed conversion ratio (FCR).

The BOD of a given feed will vary with the feed conversion efficiency. If FCE in the example above is changed to $0.455(\mathrm{FCR}=2.2), \mathrm{BOD}_{\mathrm{f}}$ becomes $1.26 \mathrm{~kg} \mathrm{O}_{2} \mathrm{~kg}^{-1}$. 
Improving FCE to $0.667(\mathrm{FCR}=1.5)$ would lower $\mathrm{BOD}_{\mathrm{f}}$ to $1.17 \mathrm{~kg} \mathrm{O}_{2} \mathrm{~kg}^{-1}$ feed. Percentages of carbon and nitrogen in feed vary with differences in percentages of major ingredients contained in feed. For example, average percentages of carbon in carbohydrates, proteins, and fats are 40, 53 and $77.2 \%$, respectively. Increasing the proportion of ingredients with high protein content or with high fat content will increase the carbon content of feed. Percentage nitrogen will vary with the amount of protein and can be estimated as crude protein divided by 6.25 .

The proposed method for estimating BOD of feed obviously would be facilitated by more data on composition of shrimp feeds and shrimp. However, until such data are available, it will suffice to use a $\mathrm{BOD}_{\mathrm{f}}$ value of $1.2 \mathrm{~kg} \mathrm{O}_{2} \mathrm{~kg}^{-1}$ feed.

\section{Mechanical Aeration}

\section{Aerators}

Several types and sizes of aerators are used in aquaculture to include vertical pumps, pump sprayers, diffused-air systems, propeller-aspirator pumps and paddlewheels ranging in size from 0.5 to 10 horsepower (hp): $1 \mathrm{hp}=0.746 \mathrm{~kW}$ (kilowatt). Paddlewheel aerators are used almost exclusively in Asian shrimp farming, but propeller-aspirator-pump aerators such as the Aire- $\mathrm{O}_{2}$ (Aeration Industries, Chaska, Minnesota) are popular in some areas. Paddlewheel aerators used in Asian shrimp farming are manufactured by several companies in Asia and the paddlewheels of these devices tend to have a similar design (Fig. 2). There are two basic styles of Asian paddlewheel aerators: 1 and $2 \mathrm{hp}$ units have an electric motor and paddlewheels mounted on floats (Fig. 3). Larger units have 5- to 10-hp electric motors or internal combustion engines on the pond bank which are attached to the paddlewheels mounted on floats (Fig. 3).

The oxygenation efficiency of aerators has been determined in standard oxygen transfer tests and reported in kilograms of oxygen transferred from air to water per kilowatt-hour (kW.hr) of electricity used by the aerator motor (Boyd 1998). Paddlewheel aerators used in channel catfish farming in the United States (Fig. 4) have standard oxygen transfer efficiencies (SAEs) of 2.0 to $2.8 \mathrm{~kg} \mathrm{O}_{2} \mathrm{~kW}^{-1} \cdot \mathrm{hr}^{-1}$ (Boyd 1998). Recent tests of paddlewheel aerators used in Asia shrimp farming revealed SAEs of 0.8 to $1.5 \mathrm{~kg} \mathrm{O}_{2} \mathrm{~kW}^{-1} \cdot \mathrm{hr}^{-1}$ (C. E. Boyd, unpublished data). The Aire- $\mathrm{O}_{2}$ aerators are more efficient in transferring oxygen to water than Asian-style paddlewheel aerators (Boyd and Tucker 1998), but they are more expensive per horsepower. There appears to be 
great opportunity for improving the performance of Asian-made paddlewheel aerators by incorporating some of the design features of more efficient aerators.

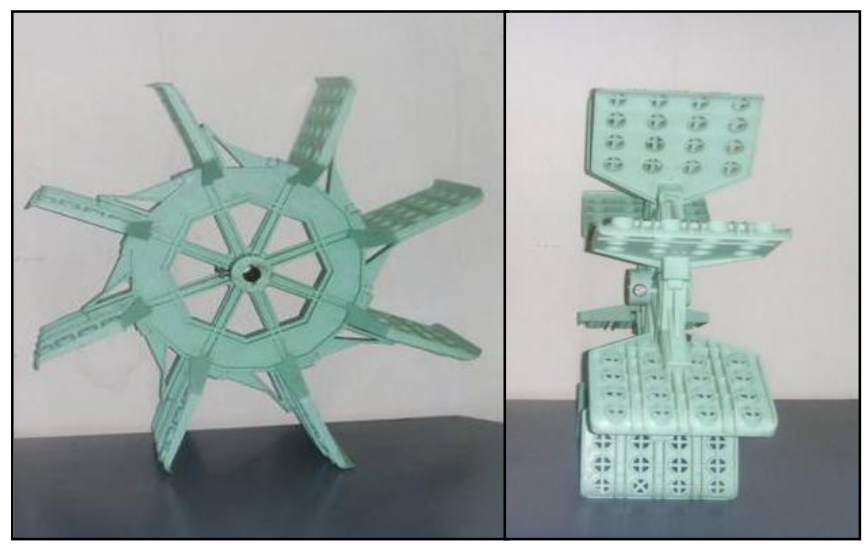

Fig. 2. Typical paddle for Asian-style paddlewheel aerators.

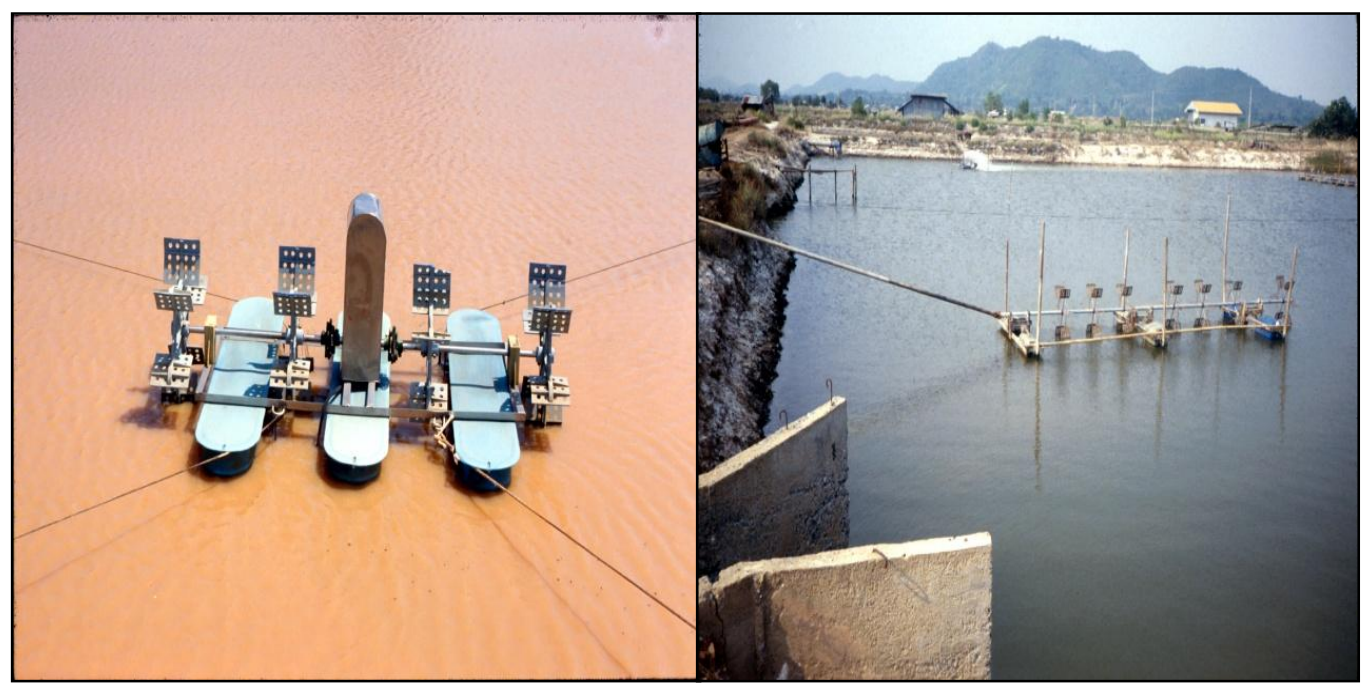

Fig. 3. Asian-style paddlewheel aerators. Left: motor attached to floating frame. Right: motor positioned on the bank and connected to the floating paddlewheel by drive shaft.

Data from an intensive shrimp farm with production of $6,000 \mathrm{~kg}^{\cdot \mathrm{ha}^{-1}}$ per crop and a feed conversion ratio of 1.75 were obtained and used to estimate the cost of aeration per tonne of shrimp (Table 1). The cost of aeration was also computed for the same amount of aeration and shrimp production assuming that ponds were aerated with more efficient aerators such as those used in channel catfish farming in the United States (Table 1). The results show that the cost of aeration would decline from US $\$ 0.536 \mathrm{~kg}^{-1}$ to US\$0.345 $\mathrm{kg}^{-1}$. 


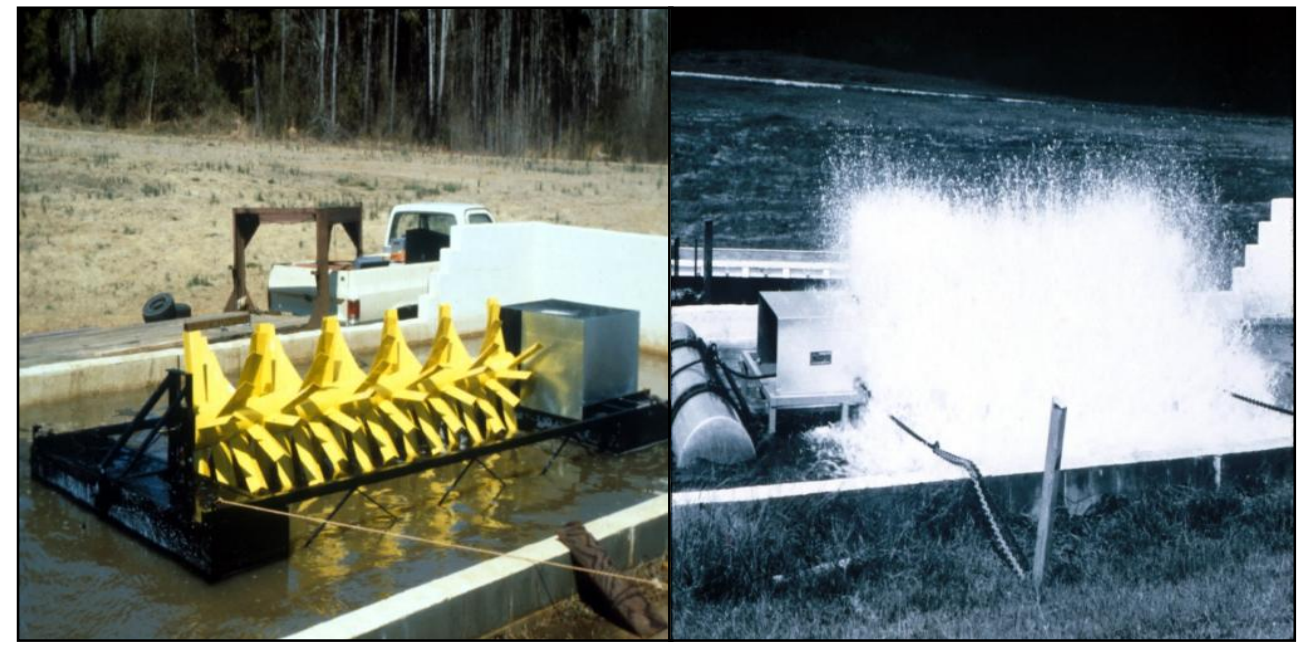

Fig. 4. Floating electric paddlewheel aerator used in channel catfish farming in the United States.

The US-style paddlewheel aerators are fabricated of mild steel and would corrode badly in saline-water ponds. However, preliminary studies have shown that the design, which is described in detail elsewhere (Boyd, 1998), can be modified to fabricate more efficient plastic paddlewheels for retrofitting Asian-style aerators currently in use. Alternatively, the aerator design used in the United States is not protected by international patents and could be adopted in its entirety and used by Asian aerator manufacturers.

Table 1. Estimation of total aeration cost in United States dollars for producing $6,000 \mathrm{~kg}^{\cdot \mathrm{ha}^{-1}}$ shrimp at a feed conversion ratio of 1.75 using aerators of different standard aeration efficiencies (SAE).

\begin{tabular}{lll}
\hline \multirow{2}{*}{ Variable } & \multicolumn{2}{c}{$\mathrm{SAE}\left(\mathrm{kg} \mathrm{O}_{2} \cdot \mathrm{kW}^{-1} \cdot \mathrm{h}^{-1}\right)$} \\
\cline { 2 - 3 } & \multicolumn{1}{c}{1.1} & \multicolumn{1}{c}{1.9} \\
\hline Aeration rate $\left(\mathrm{kW} \cdot \mathrm{ha}^{-1}\right)$ & 402 & $5.2\left(\approx 7 \mathrm{hp}^{-1} \mathrm{ha}^{-1}\right)$ \\
Aerator cost per unit $\left(\$ \mathrm{~kW}^{-1}\right)$ & 3,618 & 603 \\
Aerator purchase cost $\left(\$ \cdot \mathrm{ha}^{-1}\right)$ & 10 & 3,136 \\
Aerator service life $(\mathrm{crops})$ & 363 & 10 \\
Aerator purchase cost $\left(\$ \mathrm{ha}^{-1} \cdot \mathrm{yr}^{-1}\right)$ & 40 & 314 \\
Aerator maintenance cost $\left(\$ \mathrm{~kW}^{-1} \cdot \mathrm{crop}^{-1}\right)$ & 360 & 60 \\
Aerator maintenance cost $\left(\$ \mathrm{ha}^{-1} \mathrm{crop}^{-1}\right)$ & 722 & 312 \\
Total aerator cost $\left(\$ \mathrm{ha}^{-1} \mathrm{crop}^{-1}\right)$ & 20,790 & 626 \\
Electricity use $\left(\mathrm{kW} \cdot \mathrm{hr}^{-1} \cdot \mathrm{crop}^{-1}\right)$ & $\$ 0.12$ & 12,036 \\
Electricity rate $\left(\$ \mathrm{~kW}^{-1} \cdot \mathrm{hr}^{-1}\right)$ & 2,495 & $\$ 0.12$ \\
Electricity cost $\left(\$ \mathrm{ha}^{-1} \cdot \mathrm{crop}^{-1}\right)$ & 3,217 & 1,444 \\
Total cost of aeration $\left(\$ \mathrm{ha}^{-1} \cdot \mathrm{crop}^{-1}\right)$ & 0.536 & 2,070 \\
Total cost of aeration $\left(\$ \mathrm{~kg}^{-1} \cdot \mathrm{shrimp}^{-1}\right)$ & & 0.345 \\
\hline
\end{tabular}




\section{Aeration requirements}

The importance of adequate aeration is underscored by a study that showed improved survival, production and feed conversion ratio for L. vannamei in ponds with higher daily minimum dissolved oxygen concentration (Table 2). Most shrimp farmers base the amount of aeration on the widely-held opinion that $1 \mathrm{hp}$ of aeration will support 400 to $500 \mathrm{~kg}$ of shrimp. Intensive shrimp farmers in Asia apparently use sufficient aeration, because feed conversion ratios are usually below 2.0. The calculation of aeration requirement, however, may be more objectively made from projected maximum daily feeding rate, minimum acceptable daily dissolved oxygen concentration, feed biochemical oxygen demand and aerator SAE (Boyd 2009).

The amount of aeration applied to ponds should supply enough dissolved oxygen to satisfy $\mathrm{BOD}_{\mathrm{f}}$ and prevent dissolved oxygen concentration from falling below an acceptable minimum level $\left(3 \mathrm{mg} \mathrm{L}^{-1}\right.$ often is considered an acceptable minimum concentration in shrimp ponds). The feeding rate in a pond with a final harvest biomass of 6,000 kg ha ${ }^{-1}$ of shrimp would be around $150 \mathrm{kgha}^{-1}$ day $^{-1}$ (Wickins and Lee 2002). Assuming a $\mathrm{BOD}_{\mathrm{f}}$ of $1.2 \mathrm{~kg} \mathrm{O}_{2} \mathrm{~kg}^{-1}$, the daily $\mathrm{BOD}_{\mathrm{f}}$ load would be $180 \mathrm{~kg}^{\cdot} \mathrm{ha}^{-1} \mathrm{day}^{-1}$. Although the daily $\mathrm{BOD}_{\mathrm{f}}$ load is not expressed completely during the day that it applied, shrimp and bacteria respire continuously, and waste from previous days is also being decomposed. It seems reasonable to assume that the daily expression of $\mathrm{BOD}_{\mathrm{f}}$ is roughly equivalent to the daily $\mathrm{BOD}_{\mathrm{f}}$ load. Moreover, feed is applied to shrimp ponds several times per day, and the rate of expression of $\mathrm{BOD}_{\mathrm{f}}$ likely is relatively constant $7.5 \mathrm{~kg} \mathrm{O}_{2} \mathrm{hr}^{-1}$ in this example.

Table 2. Effect of different, average early morning dissolved oxygen concentrations on shrimp survival, yield, and feed conversion ratio (FCR) in ponds stocked at 33 postlarvae $\mathrm{m}^{-2}$. Each treatment was replicated three times. Source: McGraw et al. (2001).

\begin{tabular}{cccc}
\hline $\begin{array}{c}\text { Early morning dissolved } \\
\text { oxygen }\left(\mathbf{m g} \mathbf{L}^{\mathbf{- 1}}\right)\end{array}$ & $\begin{array}{c}\text { Survival } \\
(\mathbf{\%})\end{array}$ & $\begin{array}{c}\text { Shrimp yield } \\
\left(\mathbf{k g} \mathbf{h a}^{\mathbf{- 1}}\right)\end{array}$ & FCR \\
\hline 2.32 & 42 & 2,976 & 2.64 \\
2.96 & 55 & 3,631 & 2.21 \\
3.89 & 61 & 3,975 & 1.96 \\
\hline
\end{tabular}

The standard aerator testing procedure (American Society of Civil Engineers, 1992) measures the kilograms of oxygen per kilowatt-hour that an aerator will transfer to clean freshwater at $20{ }^{\circ} \mathrm{C}$ containing $0 \mathrm{mg}^{\cdot} \mathrm{L}^{-1}$ dissolved oxygen. The aeration efficiency under conditions existing in shrimp ponds can be estimated by the equation: 


$$
\mathrm{AE}=\mathrm{SAE} \frac{\mathrm{C}_{\mathrm{sp}}-\mathrm{C}_{\mathrm{m}}}{\mathrm{C}_{20 \mathrm{~S}}} 1.024^{\mathrm{t}-20} \alpha
$$

where $\mathrm{AE}=$ aeration efficiency $\left(\mathrm{kg} \mathrm{O}_{2} \mathrm{~kW}^{-1} \cdot \mathrm{hr}^{-1}\right) ; \mathrm{SAE}=$ standard aeration efficiency $\left(\mathrm{kg} \mathrm{O}_{2} \mathrm{~kW}^{-1} \cdot \mathrm{hr}^{-1}\right) ; \mathrm{C}_{\mathrm{sp}}=$ concentration of dissolved oxygen at saturation in pond $\left(\mathrm{mg}^{-1}\right) ; \mathrm{C}_{\mathrm{m}}=$ measured dissolved oxygen concentration in pond $\left(\mathrm{mg}^{\cdot} \mathrm{L}^{-1}\right) ; \mathrm{C}_{20 \mathrm{~s}}=$ concentration of dissolved oxygen at $20{ }^{\circ} \mathrm{C}$ and salinity of pond water $\left(\mathrm{mg}^{\cdot} \mathrm{L}^{-1}\right) ; \alpha=$ 0.92 . The $\alpha$ value is the rate at which a mechanical aerator will transfer oxygen to pond water divided by the rate that it will aerate clean freshwater. This value averaged 0.92 for water samples from a large number of aquaculture ponds (Shelton and Boyd 1983).

The SAE value for the more efficient Asian style paddlewheel aerators is $1.5 \mathrm{~kg}$ $\mathrm{O}_{2} \mathrm{~kW}^{-1} \cdot \mathrm{hr}^{-1}$. Enough aerators should be placed in ponds to prevent dissolved oxygen concentration from falling below $3 \mathrm{mg}^{-1}$. In a pond with a water temperature of $28{ }^{\circ} \mathrm{C}$ and $30 \mathrm{ppt}$ salinity, the AE calculated with Equation 4 for an aerator with an SAE of 1.5 $\mathrm{kg} \mathrm{O}_{2} \mathrm{~kW}^{-1} \cdot \mathrm{hr}^{-1}$ is $0.792 \mathrm{~kg} \mathrm{O}_{2} \mathrm{~kW}^{-1} \cdot \mathrm{hr}^{-1}$. Dividing the amount of oxygen necessary to satisfy the BOD imposed by feed ( $7.5 \mathrm{~kg} \mathrm{O}_{2} \mathrm{ha}^{-1} \mathrm{hr}^{-1}$ in this example) by AE gives an aeration requirement of $9.4 \mathrm{~kW} \cdot \mathrm{ha}^{-1}$ to maintain a dissolved oxygen concentration of 3 $\mathrm{mg} \mathrm{L}^{-1}$ or more. Aerators are usually sized in horsepower $(1 \mathrm{~kW}=0.746 \mathrm{hp})$, and about $12.6 \mathrm{hpha}^{-1}$ of aeration would be necessary.

The calculations used above for computing aeration requirement may be combined into the following equation:

$$
\mathrm{AR}=\frac{\left(\mathrm{BOD}_{\mathrm{f}}\right)(\mathrm{FR})}{(\mathrm{AE})(24 \mathrm{hr})(0.746)}
$$

where $\mathrm{AR}=$ aeration requirement $(\mathrm{hp} / \mathrm{ha}) ; \mathrm{FR}=$ maximum daily feeding rate $\left(\mathrm{kg}^{\circ} \mathrm{ha}^{-1} \cdot \mathrm{day}^{-1}\right) ; \mathrm{AE}=$ aeration efficiency $\left(\mathrm{kg} \mathrm{O}_{2} \cdot \mathrm{kW}^{-1} \cdot \mathrm{hr}^{-1}\right)$ calculated with Equation 4 for a dissolved oxygen concentration of $3 \mathrm{mg} \cdot \mathrm{L}^{-1}$.

When applied to typical conditions for P. vannamei culture, the method for estimating aeration requirement outlined above suggests that $1 \mathrm{hp}$ of aeration with typical aerators is adequate for $475 \mathrm{kgha}^{-1}$ of shrimp. This agrees well with the common belief that $1 \mathrm{hp}$ of aeration will support 400 to $500 \mathrm{~kg}$ of shrimp. However, the use of $\mathrm{BOD}_{\mathrm{f}}$ and aerator $\mathrm{SAE}$ for estimating aeration requirements would allow for more refined estimates of the amount of mechanical aeration needed in shrimp ponds. It is essential to have sufficient aeration to prevent low dissolved oxygen concentration from stressing the culture species, but electricity for powering aerators is expensive, and excessive aeration is wasteful. 


\section{Use of aeration}

It is suspected that an even greater reduction in aeration cost could be achieved by turning off some aerators during the daytime when dissolved oxygen concentration is high. In catfish farming in the United States, aeration is normally applied only at night. However, shrimp live on the bottom and water circulation caused by aerators is needed during the day to avoid adverse conditions at the sediment water interface. Nevertheless, if daytime aeration could be reduced by only $25 \%$, an electricity savings of $12.5 \%$ would be realized. This would reduce the cost of aeration by US $\$ 0.052 \mathrm{~kg}^{-1}$ in ponds with Asian-style aerators, and by US\$0.030 $\mathrm{kg}^{-1}$ in ponds with US-style aerators.

An alternative to daytime aeration might be the use of mechanical water circulators (Howerton et al. 1993). These devices could possibly create water circulation at a lower power input than is possible with aerators. They might also conserve dissolved oxygen because surface aerators cause loss of dissolved oxygen from ponds when dissolved oxygen concentration is above saturation during late morning and early afternoon. Research findings are conflicting on the benefits of water circulators in reducing the amount of time that aerators must be operated (Tucker and Steeby 1995); thus, farm trials are needed to ascertain whether or not this technology has merit.

Aerators cause considerable erosion of the insides of embankments and bottoms of ponds. Producers spend considerable effort and expense to remove sediment that accumulates in the central areas of ponds during each crop and disposal of this sediment can cause salination (Boyd et al. 1994). This problem can be lessened if embankments are sloped $2: 1$ or 3:1 on the wet side and aerators positioned at least 2 or $3 \mathrm{~m}$ beyond the toes of the embankments. In addition, aerators should be positioned so that strong currents should not impinge upon embankments. However, the most reliable way of avoiding serious erosion is to cover vulnerable parts of pond bottoms and embankments with plastic liners.

A few farms have resorted to completely covering the insides of ponds with plastic liners to allow greater amounts of aeration. Liners are expensive, and production must be high to make this technology economically feasible. In one production technique used in lined ponds, yields of 12,000 to $15,000 \mathrm{kgha}^{-1}$ are achieved in greenwater ponds. Dead algae accumulate on pond bottoms, and some producers use suction pumps to remove this material. This reduces the demand for oxygen in the pond, but it does so at the environmental expense of externalizing part of the waste load. The most 
environmentally-responsible approach would be to discharge the sludge into a wastewater treatment pond before releasing it into the environment.

The heterotrophic "floc" system (McIntosh 1999, 2008) requires lined ponds, and some shrimp farms in Asia have installed "floc" systems. Production may exceed $20,000 \mathrm{~kg}^{\cdot \mathrm{ha}^{-1}}$ in such systems, and 30 to $40 \mathrm{hp}^{\cdot \mathrm{ha}^{-1}}$ of aeration may be used. Pond water becomes so turbid from suspended organic particles that phytoplankton growth is light limited. The floc is largely suspended in the water by aerator mixing, and it harbors a high abundance of bacteria. Shrimp eat the bacterial floc, thereby lessening the amount of feed that must be applied.

\section{Acidity from Nitrification}

The portion of feed nitrogen not included in shrimp at harvest can potentially enter pond water as ammonia nitrogen. The potential load of ammonia nitrogen in a pond producing $6,000 \mathrm{~kg}^{\cdot h^{-1}}$ shrimp will be estimated assuming that feed is $5.6 \%$ nitrogen (35\% crude protein), FCR is 1.75 and shrimp contain $2.86 \%$ nitrogen. The calculations follow:

Feed $\mathrm{N}=6,000 \mathrm{~kg}$ shrimp $\mathrm{ha}^{-1} \times 1.75 \times 0.056 \mathrm{~kg} \mathrm{~N}^{\circ} \mathrm{feed}^{-1} \quad=588 \mathrm{~kg} \mathrm{~N} \cdot \mathrm{ha}^{-1}$;

Shrimp $\mathrm{N}=6,000 \mathrm{~kg}$ shrimp $\mathrm{ha}^{-1} \times 0.0286 \mathrm{~kg} \mathrm{~N}^{*} \mathrm{~kg}^{-1}$ shrimp $=171.6 \mathrm{~kg} \mathrm{~N} \cdot \mathrm{ha}^{-1}$;

Ammonia nitrogen load $=$ Feed $\mathrm{N}-$ shrimp $\mathrm{N} \quad=416.4 \mathrm{~kg} \mathrm{~N} \cdot \mathrm{ha}^{-1}$.

Much of the ammonia nitrogen in pond water is oxidized to nitrate (Equation 2). This oxidation releases hydrogen ions that can reduce the total alkalinity of pond water. Alkalinity is expressed as equivalent calcium carbonate and the loss of alkalinity can be illustrated as follows:

$$
\mathrm{CaCO}_{3}+2 \mathrm{H}^{+}=\mathrm{Ca}^{2+}+\mathrm{CO}_{2}+\mathrm{H}_{2} \mathrm{O}
$$

Based on stoichiometry (Equations 2 and 6), oxidation of one unit of ammonia nitrogen can cause a reduction in total alkalinity of 7.14 units. The potential acidity resulting from feed in the example above would be equivalent to $2,973 \mathrm{~kg} \mathrm{CaCO}_{3}$ (total alkalinity) $\mathrm{ha}^{-1}-0.28 \mathrm{~kg} \mathrm{CaCO}_{3} \mathrm{~kg}^{-1}$ feed. The actual amount of liming material would vary with feed protein concentration and FCR, but for practical purposes, 0.30 to 0.35 $\mathrm{kg} \mathrm{CaCO}_{3}$ equivalent $\mathrm{kg}^{-1}$ feed should suffice. Liming materials do not react completely, so some producers may want to apply about 1.5 times more liming material than the minimum amount needed to neutralize acidity from feed. It is important to 
note that liming materials vary in their ability to neutralize acidity, for example, calcium oxide $(\mathrm{CaO})$ and calcium hydroxide $\left[\mathrm{Ca}(\mathrm{OH})_{2}\right]$ are $135 \%$ and $179 \%$ more effective, respectively than calcium carbonate $\left(\mathrm{CaCO}_{3}\right)$. An equation is available for more exact estimation of feed lime requirement (Boyd 2007), but the information needed to use the equation will seldom be available to small-scale, shrimp producers. In highly intensive shrimp culture, an amount of liming material sufficient to neutralize the potential acidity of the feed input of the previous week should probably be calculated and applied at the end of each week of culture.

Seawater and brackishwater are usually high in alkalinity, and in ponds with high water exchange rates, total alkalinity may not decline. Also, in ponds with earthen bottoms that are limed during pond preparation, calcium carbonate in soil may dissolve to replenish alkalinity. However, in intensive ponds without water exchange, and especially in ponds with liners, total alkalinity concentration will decline during the production cycle.

\section{Water Quality Amendments}

Shrimp farms in Asia seldom use high rates of water exchange, as was once common practice. The three most effective measures for maintaining water quality in ponds are conservative feeding practices to avoid overfeeding, mechanical aeration, and liming. Many producers, nevertheless, apply many chemical and biological amendments for the purpose of improving water quality. A study by Gräslund et al. (2003) identified 290 different amendments used by shrimp farmers in Thailand. However, only a few of these amendments are used frequently. Many farmers apply zeolite for ammonia removal, and microbial products such as live bacterial inocula and enzyme preparation to enhance natural microbial processes. There is no sound scientific evidence that either of these practices is effective in pond aquaculture (Boyd and Tucker 1998; Mischke 2003; Boyd and Silapajarn 2006). Fortunately, neither zeolite nor microbial amendments have negative effects on health and growth of aquaculture animals, the environment or food safety. Benzalkonium chloride (BKC) is also commonly used at about $1.5 \mathrm{mg} \cdot \mathrm{L}^{-1}$ to control phytoplankton (Lee et al. 1994). The effectiveness of this practice is questionable and the possible negative environmental impacts have not been studied. Sodium nitrate may be applied to ponds to oxidize the sediment-water interface. This practice improved the redox potential at the sediment surface in freshwater ponds (Chainark and Boyd 2010), but its effects on shrimp production are not known. Some producers apply iron or aluminum compounds to remove phosphorus from pond waters in an effort to lessen phytoplankton abundance. 
There is some evidence that these products can be effective (Boyd et al. 2008) and further research is needed.

\section{Low-salinity Shrimp Farming}

There is considerable production of shrimp in water of 1 to $5 \mathrm{ppt}$ salinity in several Asian countries. In Thailand, brine solution from coastal seawater evaporation ponds is often added to freshwater in ponds to provide a suitable salinity for shrimp culture (Limsuwan et al. 2002). Ionic imbalances do not occur in pond water because the brine solution contains the full complement of ions of seawater in concentrated form (Boyd et al. 2002). At locations where saline groundwater is used to fill ponds, waters may be deficient in potassium and magnesium. Muriate of potash (fertilizer-grade potassium chloride) and sulfate of potash magnesia (a potassium magnesium sulfate fertilizer sold under the trade name $\mathrm{Kmag}^{\circledR}$ ) applied to low-salinity shrimp ponds can be highly effective in increasing potassium and magnesium concentrations and correcting ionic imbalances (McNevin et al. 2004).

Low-salinity shrimp culture can cause salination through seepage into groundwater and overflow, or intentional discharge into surface water (Braaten and Flaherty 2001; Boyd et al. 2006). Inland shrimp farming has been banned in freshwater areas in Thailand (Fegan 2001a), but the definition of freshwater areas has been subject to interpretation and the practice persists. Best practices for avoiding salination are to site, design, construct and operate ponds in a way that minimizes seepage, overflow and harvest effluent. Low-salinity shrimp farming is currently being conducted in some freshwater areas without causing serious salination (Boyd et al. 2006).

\section{Environmental Issues}

Complaints by environmentalists have led to the development of codes of conduct and best management practices (BMPs) for shrimp farming in most major shrimp-producing countries (Boyd 2003). Moreover, governments have enacted regulation for reducing environmental impacts (Tookwinas 1996). For example, the Pollution Control Board and National Environmental Board in Thailand have limited biochemical oxygen demand and suspended solids in effluent discharge to a maximum of $20 \mathrm{mg}^{\cdot} \mathrm{L}^{-1}$ and $70 \mathrm{mg}^{\cdot} \mathrm{L}^{-1}$, respectively (Fegan 2001b). The standards are initially limited to farms larger than 1.5 ha. Governments of several countries prohibited construction of shrimp farms in mangrove forests, established rules about importing broodstock and postlarvae, restricted the use of some antibiotics and implemented effluent regulations. There is increased awareness of environmental protection among 
shrimp producers and production practices today are less harmful to the environment than those used in the past.

A study in Bangladesh (Wahab et al. 2003) revealed that effluent water from extensive shrimp farms was of higher quality than the water entering the farms. Feed is not widely used in extensive farms and there is little use of chemicals other than liming materials and fertilizers. Thus, environmentalists tend to favor extensive shrimp production over more intensive culture. Nevertheless, there is a major trade-off. Extensive shrimp farms are more likely than semi-intensive and intensive farms to be constructed in mangrove habitats or other sensitive wetlands, and the area of land devoted to producing 1 tonne of shrimp is 5 to 25 times greater than the area necessary to produce 1 tonne of shrimp by more intensive production (Boyd et al. 2007).

The public is becoming more environmentally aware and there is a growing market for products produced by using environmentally- and socially-responsible methods. There is also great concern by consumers regarding food safety because of many widely publicized incidences of food tainted by microbial and chemical contaminants. Therefore, firms purchasing large amounts of shrimp such as wholesalers, supermarket chains and restaurants are seeking shrimp that are of high quality, free of contaminants and produced by environmentally- and sociallyresponsible techniques. They want to be able to trace shrimp back to the farm and pond of origin, and in addition, to have access to records of all treatments made to the shrimp should questions arise about food safety.

The governments of importing countries make inspections of shrimp at their port of entry, but they only sample a small percentage of arriving shipments. Some countries also require shrimp and other fisheries products to be labeled with their country of origin and to their means of production (whether they were wild-caught or produced by aquaculture). However, a growing segment of the population wants additional assurance that their food is safe and was produced responsibly.

The Global Aquaculture Alliance (GAA), an aquaculture industry oriented nongovernmental organization headquartered in St. Louis, Missouri, USA, developed standards for responsible shrimp production, and the Aquaculture Certification Council (ACC) certifies hatcheries, feed mills, farms and processing plants willing to adopt GAA Best Aquaculture Practice (BAP) standards. Wal-Mart Stores, Inc., the world's largest public cooperation by revenue and several other large shrimp buyers are purchasing ACC-certified shrimp exclusively. GLOBAL G.A.P., a private sector body with main offices in Cologne, Germany, sets voluntary standards for certification of agriculture products worldwide, and recently designed standards for shrimp. In 
addition, several large food retailers, e.g. Wegmans Food Markets, Whole Foods and Costco (USA), Marks and Spencer and Tesco (UK) and Carrefour (France) as well as Bon Appetit Management Company, a catering and small restaurant management firm have already developed or are in the process of developing purchasing standards. These buyers seek producers willing to supply shrimp produced according to their purchasing standards. Some shrimp farms in Asia have been certified by ACC or are participating in one of the purchasing standards programs; more are expected to join in the future. The World Wildlife Fund also is developing standards for responsible shrimp culture through dialogues involving a wide range of stakeholders. When completed, a certifying body will be found or established.

It appears that several certification programs may result from the current effort to foster responsible shrimp farming. The Food and Agriculture Organization (FAO) of the United Nations is developing guidelines for aquaculture certification programs, and their guidelines should lead to greater uniformity among the various standards. Nevertheless, most of the standards appear to be consistent with respect to environmental issues. The major issues are as follows: selection of good sites for new farms or farm expansions; protection of mangrove and other wetlands; water pollution control; reduction in use of fish meal and fish oil in feeds; conservative feeding practices; use of farm-reared rather than wild-caught broodstock and postlarvae; more reliance on shrimp health management and less use of antibiotics for disease control; restrictions on imports of broodstock and postlarvae; retention of records on management activities. There are, however, large variations in social standards among the different certification programs, and major differences in how programs are organized, operated and administered.

\section{References}

American Society of Civil Engineers. 1992. Measurement of oxygen transfer in clean water. ANSI/ASCE 2-91, American Society of Civil Engineers, New York. 41 pp.

Baticados, M.C.L. and C.L. Pitogo. 1990. Chlorination of seawater used for shrimp culture. The Israeli Journal of Aquaculture - Bamidgeh 42:128-130.

Boyd, C.A., C.E. Boyd, A.A. McNevin and D.B. Rouse. 2006. Salt discharge from an inland farm for marine shrimp in Alabama. Journal of the World Aquaculture Society 37:345355.

Boyd, C.E. 1998. Pond water aeration systems. Aquacultural Engineering 18:9-40.

Boyd, C.E. 2007. Nitrification important process in aquaculture. Global Aquaculture Advocate 10(3):64-66.

Boyd, C.E. 2009. Estimating mechanical aeration requirement in shrimp ponds form the oxygen demand of feed. In: The rising tide, Proceedings of the Special Session on Shrimp 
Farming (ed. C.L. Browdy and D.E. Jory), pp 230-234. World Aquaculture Society, Baton Rouge, Louisiana.

Boyd, C.E. 2003. The status of codes of practice in aquaculture. World Aquaculture 34(2):6366.

Boyd, C.E., T. Thunjai and M. Boonyaratpalin. 2002. Dissolved salts in waters for inland, lowsalinity shrimp culture. Global Aquaculture Advocate 5(3):40-45.

Boyd, C.E. and L. Massaut. 1999. Risks associated with use of chemicals in pond aquaculture. Aquacultural Engineering 20:113-132.

Boyd, C.E. and O. Silapajarn. 2006. Influence of microorganisms on water and sediment quality in aquaculture ponds. In: Microbial biotechnology in agriculture and aquaculture (ed. R.C. Ray), pp. 261-285. Science Publishers, Enfield, New Hampshire.

Boyd, C.E. and D. Teichert-Coddington. 1995. Dry matter, ash, and elemental composition of pond-cultured Penaeus vannamei and P. stylirostis. Journal of the World Aquaculture Society 26:88-92.

Boyd, C.E. and C.S. Tucker. 1998. Pond aquaculture water quality management. Kluwer Academic Publishers, Boston. 700 pp.

Boyd, C.E., P. Munsiri and B.F. Hajek. 1994. Composition of sediment from intensive shrimp ponds in Thailand. World Aquaculture 25(3):53-55.

Boyd, C.E., P. Pengseng and S. Soongsawang. 2008. Evaluation of iron and aluminum compounds for removing phosphorus turbidity from pond waters. World Aquaculture 2008, CD of Abstracts, World Aquaculture Society, Baton Rouge, Louisiana.

Boyd, C.E., C.S. Tucker, A. McNevin, K. Bostick and J. Clay. 2007. Indicators of resource use efficiency and environmental performance in fish and crustacean aquaculture. Reviews in Fisheries Science 15:327-360.

Braaten, R.O. and M. Flaherty. 2001. Salt balances of inland shrimp ponds in Thailand: implications for land and water salinization. Environmental Conservation 28:357-367.

Chainark, S. and C.E. Boyd. 2010. Water and sediment quality, phytoplankton communities, and channel catfish production in sodium-nitrate treated ponds. Journal of Applied Aquaculture 22:171-185.

Fegan, D. 2001a. Thailand's inland farming ban continues. Global Aquaculture Advocate 6(6):63-64.

Fegan, D. 2001b. Update: Shrimp farming in Southeast Asia. Global Aquaculture Advocate 4(2):81.

Fegan, D. 2002a. Current issues: Antibiotics, Penaeus vannamei. Global Aquaculture Advocate 5(4):62-63.

Fegan, D. 2002b. More shrimp-breeding programs needed in Asia. Global Aquaculture Advocate 5(1):57-57.

Fegan, D. 2007. Indian farmers consider white shrimp; fishmeal major issue. Global Aquaculture Advocate 10(2):61-62.

Gräslund, S., K. Holmström and A. Wahlström. 2003. A field survey of chemicals and biological products used in shrimp farming. Marine Pollution Bulletin 46:81-90.

Howerton, R.D., C.E. Boyd and B.J. Watten. 1993. Design and performance of a horizontal, axial-flow water circulator. Journal of Applied Aquaculture 3:163-183.

Johnson, W.W. and M.T. Finley. 1980. Handbook of acute toxicity of chemicals to fish and aquatic invertebrates. U.S. Department of the Interior, Fish Wildlife Service, Resource Publication Number 137, Washington. 98 pp. 
Lee, C., I. Chen and S. Fong. 1994. Effects of benzalkonium chloride on growth of phytoplankton. Journal of the Fisheries Society of Taiwan 21:69-77.

Limsuwan, C., T. Somsiri and S. Silarudee. 2002. The appropriate salinity level of brine water for raising black tiger prawn under low-salinity conditions. Aquatic Animal Health Research Institute Newsletter 11:2-4.

McIntosh, R.P. 1999. Changing paradigms in shrimp farming, I. General description. Global Aquaculture Advocate 2(4/5):40-47.

McIntosh, R.P. 2008. Advancing shrimp farm technologies support greater efficiencies, sustainability. Global Aquaculture Advocate 11(5):88-90.

McGraw, W., D. Teichert-Coddington, D.B. Rouse and C.E. Boyd. 2001. Higher minimum dissolved oxygen concentrations increase penaeid shrimp yields in earthen ponds. Aquaculture 199:311-321.

McNevin, A., C.E. Boyd, O. Silapajarn and K. Silapajarn. 2004. Ionic supplementation of pond waters for inland culture of marine shrimp. Journal of the World Aquaculture Society 35:460-467.

Mischke, C.C. 2003. Evaluation of two bio-stimulants for improving water quality in channel catfish, Ictalurus puncatatus, production ponds. Journal of Applied Aquaculture 14:163-169.

Potts, A.C. and C.E. Boyd. 1998. Chlorination of channel catfish ponds. Journal of the World Aquaculture Society 29:432-440.

Ruttanagosrigit, W. 1997. Organic matter dynamics in a closed, intensive culture system for black tiger prawn (Penaeus monodon). Doctor of Technical Science Dissertation, Asian Institute of Technology, Bangkok, Thailand.

Shelton, J.J., Jr. and C.E. Boyd. 1983. Correction factors for calculating oxygen-transfer rates of pond aerators. Transactions of the American Fisheries Society 112:120-122.

Suresh, A.V., C. Aceituno and L. Oliva. 2006. Pond preparation. In: Operating procedures for shrimp farming (ed. C. Boyd, D. Jory, and G. Chamberlain), pp. 54-60. Global Aquaculture Alliance, St. Louis, Missouri.

Tookwinas, S. 1996. Environmental impact assessment for intensive marine shrimp farming in Thailand. Thai Fisheries Gazette 48:119-133.

Tucker, C.S. and J.A. Steeby. 1995. Daytime mechanical water circulation of channel catfish ponds. Aquacultural Engineering 14:15-27.

Wahab, M.A., A. Bergheim and B. Braaten. 2003. Water quality and partial mass budget in extensive shrimp ponds in Bangladesh. Aquaculture 218:413-423.

White, G.C. 1992. Handbook of chlorination and alternative disinfectants. Van Nostrand Reinhold, New York. 1,308 pp.

Wickins, J.F. and D.O' Lee. 2002. Crustacean farming, $2^{\text {nd }}$ edition. Blackwell Science, Oxford. 446 pp. 